\title{
The Effect of Benomyl on the Fine Structure of Botrytis fabae
}

\author{
By D. V. RICHMOND AND R. J. PRING \\ Long Ashton Research Station, University of Bristol
}

(Accepted for publication 4 March I97I)

\begin{abstract}
SUMMARY
Conidia of Botrytis fabae germinate in the presence of sublethal concentrations of benomyl to produce swollen and distorted germ tubes which branch more frequently than those of normal conidia. Multiple germ-tube emergence also occurs to a greater extent in treated conidia.

The orientation of organelles towards the hyphal tip is disorganized in benomyltreated germ tubes. Endoplasmic reticulum which occurs as multiple strands surrounding the nuclei in normal germinating spores is broken up into a fragmented network. Part of the endoplasmic reticulum occurs as strands and vesicles close to the plasmalemma, a configuration which corresponds closely to the situation in resting conidia. The findings inchemically fixed sections are confirmed by the appearance of freeze-etched replicas. Benomyl treatment seems to stimulate lomasome formation, and freeze-etched treated nuclei appear deeply lobed and convoluted.
\end{abstract}

\section{INTRODUCTION}

Benomyl (methyl- $N$-benzimidazol-2-yl- $N$-(butylcarbamoyl) carbamate) is a new systemic fungicide which controls many phytopathogenic fungi and has some mite ovicidal properties (Delp \& Klopping, 1968). The compound has also been reported to suppress root invasion by nematodes (Miller, I969). In aqueous solution benomyl is rapidly broken down to methyl- $N$-benzimidazol-2-yl-carbamate (Clemons \& Sisler, I969); the same breakdown product has been detected in the leaves of benomyl-treated cotton plants (Sims, Mee \& Erwin, 1969). The breakdown product is as toxic as benomyl to mycelia of Neurospora crassa and Rhizoctonia solani and both compounds are more effective in preventing mycelial growth than in inhibiting spore germination (Clemons \& Sisler, 1969). Ascospores of Mycosphaerella musicola produced distorted germ tubes when incubated on banana leaves in the presence of benomyl, and the fungicide also reduced sporulation of this organism (Stover, 1969).

The fine structure of resting and germinating conidia of Botrytis fabae was described in earlier papers (Richmond \& Pring, 197I $a, b$ ). The present paper describes the cytological changes induced in germinating conidia of $B$. fabae by treatment with benomyl as seen in both chemically fixed sections and freeze-etched replicas.

\section{METHODS}

Fungus. Botrytis fabae Sardiña (strain K I73) was kindly supplied by Jealott's Hill Research Station. Conidia were washed from 7 to 9 day cultures grown on the following medium: glucose, $40 \mathrm{~g}$; ; peptone, Io g.; $\mathrm{KNO}_{3}$, O.I g.; $\mathrm{KH}_{2} \mathrm{PO}_{4}, 6.8 \mathrm{~g}$.; $\mathrm{MgSO}_{4} \cdot 7 \mathrm{H}_{2} \mathrm{O}, 2.5 \mathrm{~g}$; $\mathrm{CaCl}_{2}, 0 . \mathrm{I}$ g.; $\mathrm{FeCl}_{3}, 20 \mathrm{mg}$; agar, $20 \mathrm{~g}$./1. (Hislop, 1967). Conidia were filtered through cheese cloth, washed three times by centrifugation, then suspended in distilled water at $\mathrm{I}^{\circ}$. 

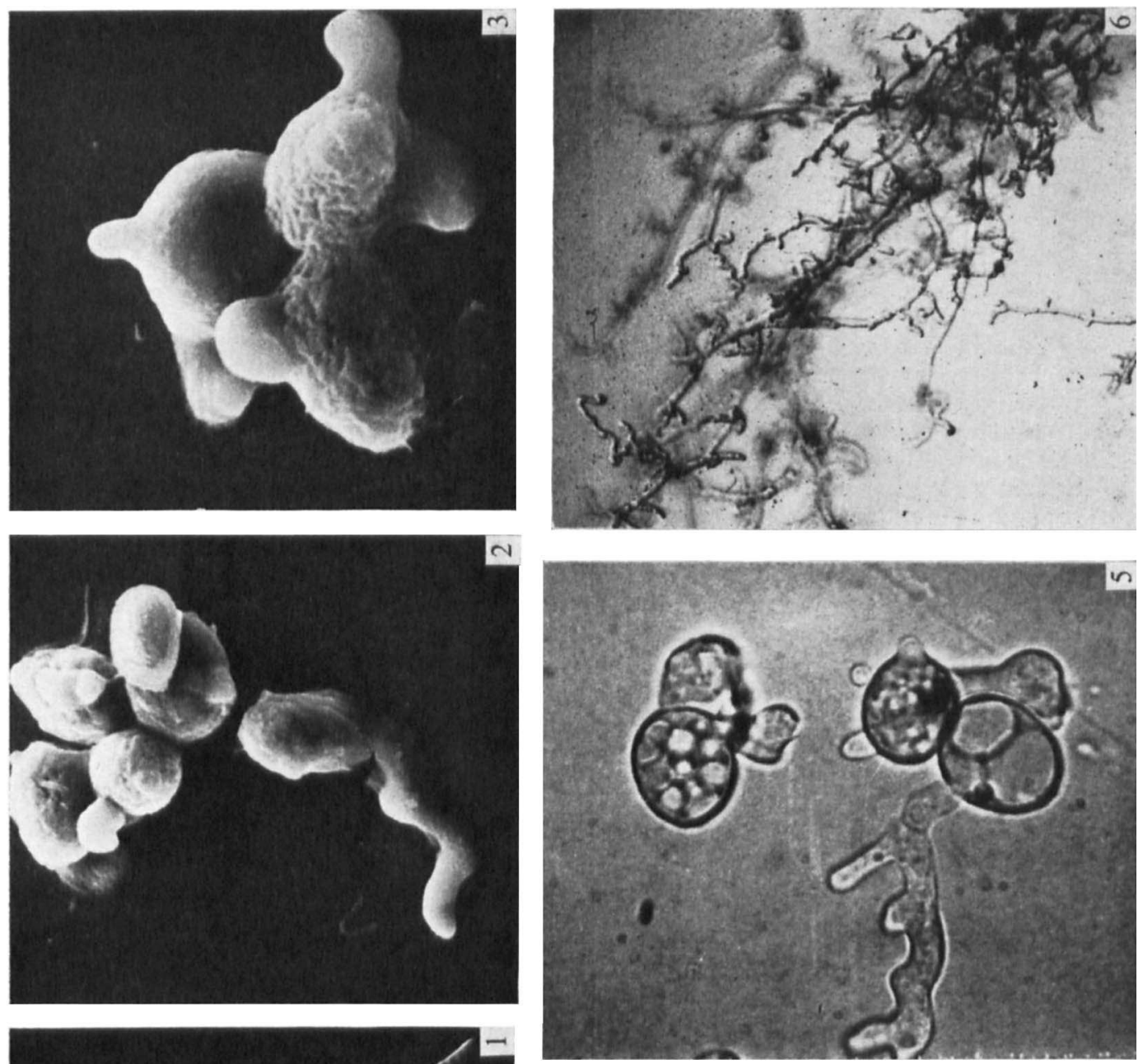

点
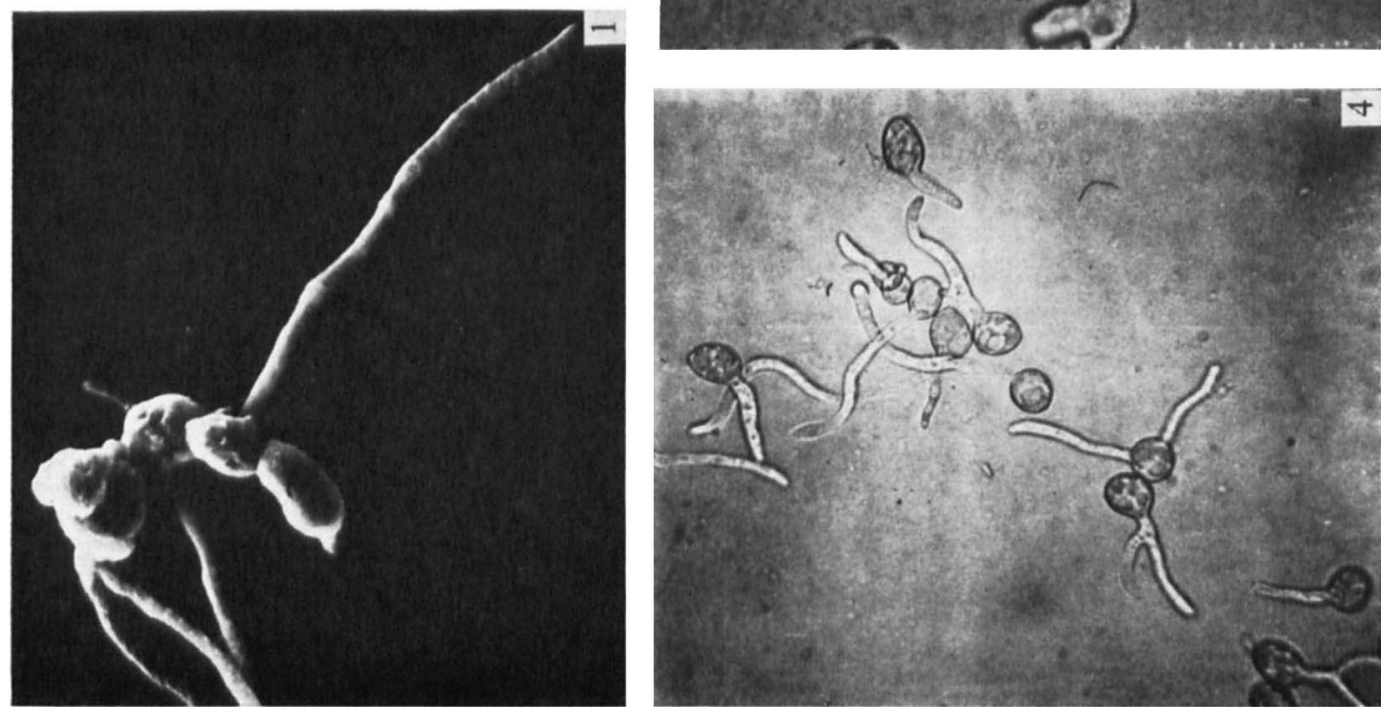
Germinating conidia were obtained by shaking for $\mathrm{I} 8 \mathrm{~h}$. at $25^{\circ}$ a conidial suspension in a $25 \%(\mathrm{v} / \mathrm{v})$ solution of the culture medium without the agar.

Electron microscopy. Conidia were fixed in $2 \%(\mathrm{w} / \mathrm{v})$ aqueous $\mathrm{KMnO}_{4}$ for $\mathrm{I}$ h. at room temperature, dehydrated through a graded acetone series and embedded in Vestopal. Sections were cut on an LKB Ultrotome, stained with lead citrate and viewed with an AEI EM6 B microscope. For freeze-etching, spores were suspended in $15 \%(\mathrm{w} / \mathrm{v})$ glycerol for I h., then treated as described by Moor (I966). Replicas were prepared in a Balzers freezeetching plant BA $360 \mathrm{M}$, and examined as above. For scanning electron microscopy suspensions of germinating conidia on coverslips were fixed in $2 \%(\mathrm{w} / \mathrm{v})$ aqueous $\mathrm{OsO}_{4}$ for $30 \mathrm{~min}$., then dehydrated in graded acetone. The coverslip was stuck to the metal specimen holder, coated under vacuum with $\mathrm{Au} / \mathrm{Pd}$ and viewed in the Stereoscan.

Fungicide. Benomyl was recrystallized with ethanol from technical grade material kindly supplied by the Du Pont Co. (U.K.) Ltd.

\section{Morphological effects of benomyl}

\section{RESULTS}

Conidia germinating in the presence of sublethal concentrations of benomyl (O.I to $0.3 \mu \mathrm{g} . / \mathrm{ml}$.) produced swollen and distorted germ tubes which branched more frequently than those of normal conidia (Pl. I, fig. I to 5). Multiple germ-tube emergence also occurred to a greater extent in treated conidia (Pl. I, fig. 3). The wrinkled appearance of the conidial surface in Stereoscan preparations (Pl. I, fig. 2,3) was probably caused by shrinkage of the spore during the vacuum treatment. A similar effect has been observed by Greenhalgh \& Evans (1968) with ascospores of Hypoxylon rubiginosum.

When conidia germinating in the presence of benomyl were transferred to a fungicide-free medium normal growth ensued. Conidia from growth-inhibiting concentrations also germinated normally when freed from fungicide. When benomyl was added to a mycelial mat of Botrytis fabae growth continued but distortions appeared in the young hyphae and branching was increased (Pl. I, fig. 6).

Effects of benomyl on fine structure. The characteristic distorted germ tubes produced when conidia germinated in the presence of benomyl could be seen in thin sections ( $\mathrm{Pl} .3,4)$ and freeze-fractured replicas (PI. 5). The thin sections showed the conidial septal pore and the freeze-fractured replica ( $\mathrm{Pl}$. 5) showed a conidium with two emerging germ tubes.

Abbreviations: ER, endoplasmic reticulum; G, glycogen; INM, inner surface of inner nuclear membrane; LI, lipid body; LO, lomasome; M, mitochondrion; N, nucleus; NP, nuclear pore; ONM, inner surface of outer nuclear membrane; PI, inner surface of plasmalemma; PO, outer surface of plasmalemma; PV, prevacuole; SP, septal pore; T, tonoplast; V, vacuole; VE, vesicle.

The bar represents I $\mu \mathrm{m}$. All magnifications are approximate.

\section{Plate I}

Fig. I. Germinating normal conidia as seen by scanning electron microscope. $\times 880$.

Fig. 2. Conidia germinating in the presence of benomyl (O.I $\mu$ g.ml) and showing distorted germ tubes. Scanning electron microscope. $\times 2600$.

Fig. 3. Conidia germinating in the presence of benomyl and showing multiple germ tubes emerging. Scanning electron microscope. $\times 1460$.

Fig. 4. Photomicrograph of germinating normal conidia. $\times 360$.

Fig. 5. Photomicrograph of conidia germinating in the presence of benomyl. $\times 880$.

Fig. 6. Photomicrograph of hypha after transference to benomyl-containing medium, showing distorted young hyphae and increased branching. $\times 180$. 


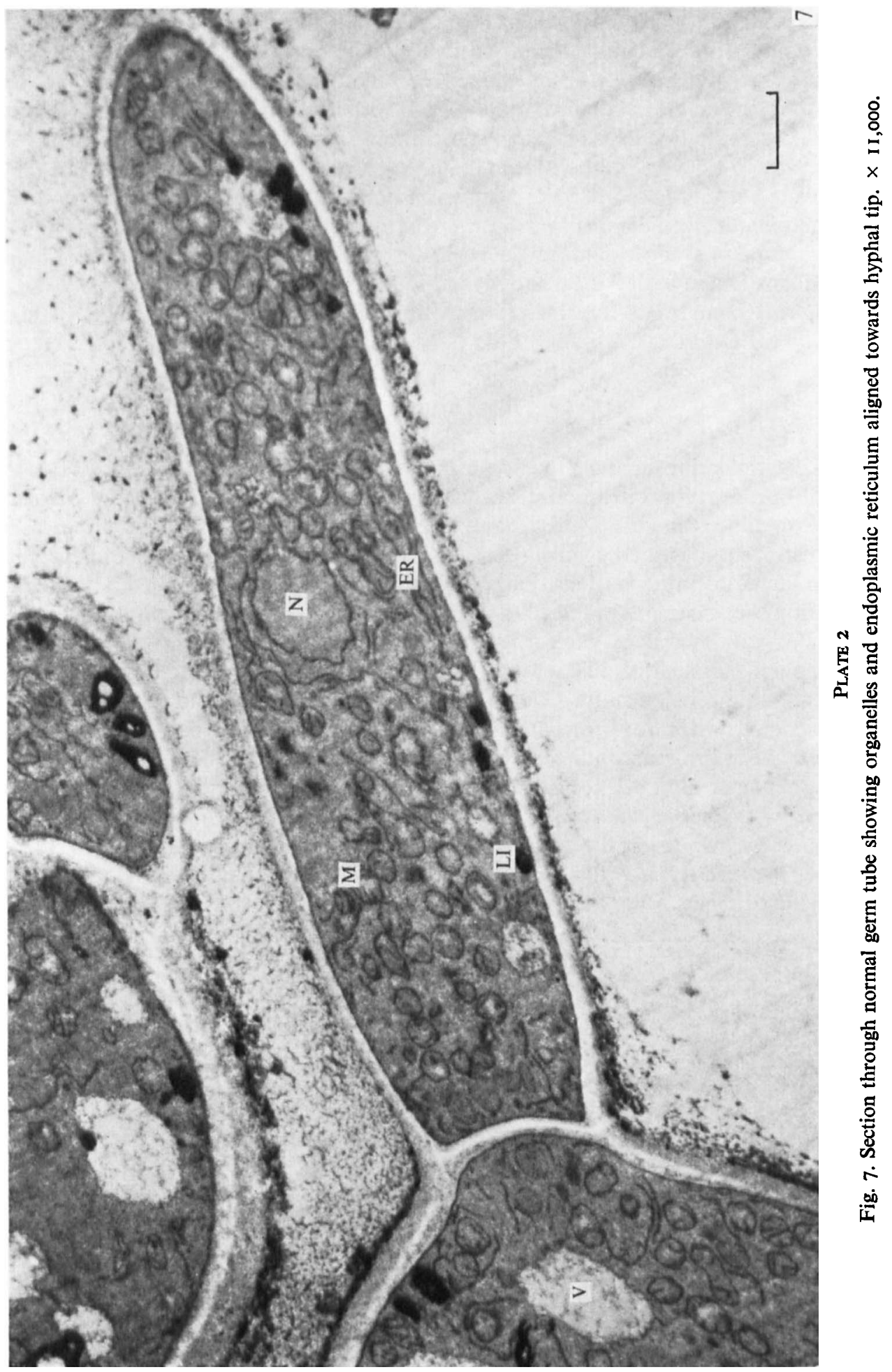



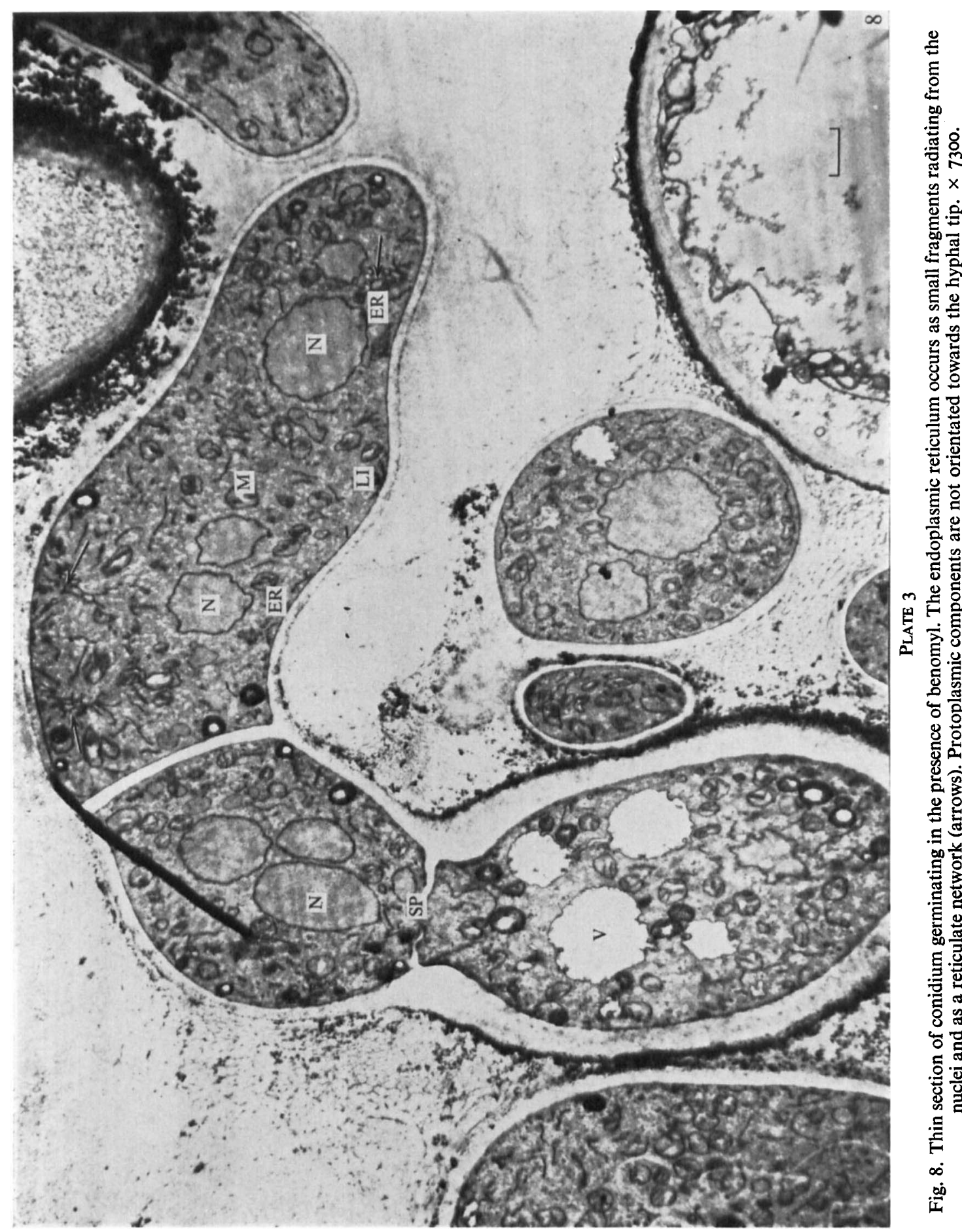


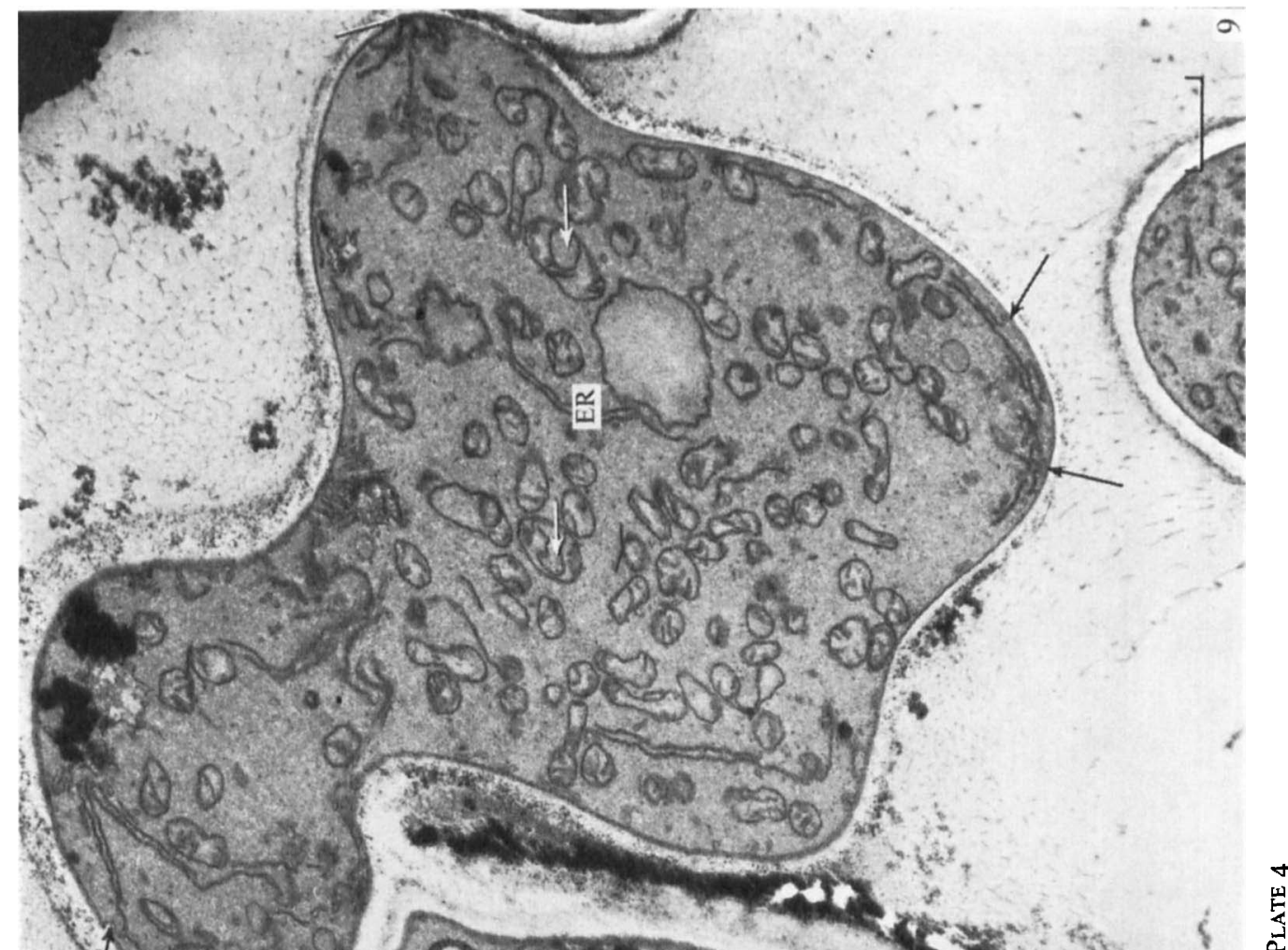

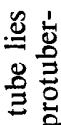

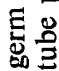

导

.

吾焉

.0.

응

空

을

近

ธี

은

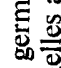

总

要

응

$\checkmark$ 合

的车 突

농웡

4

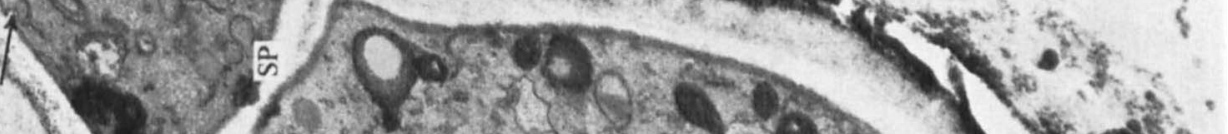

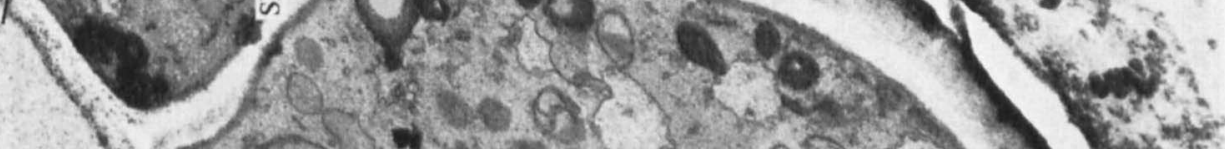

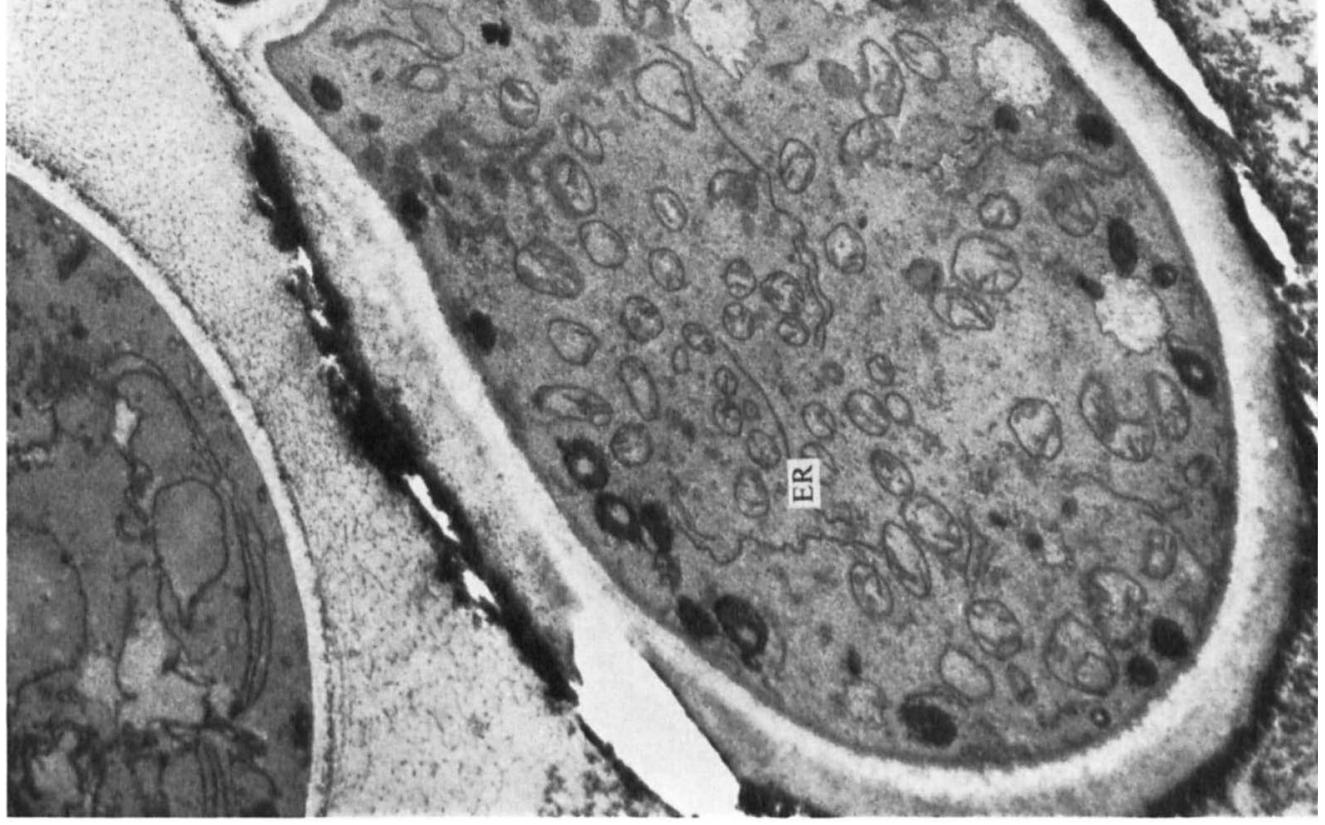

ते

है.

这

O० 8

递.

政远

吨

․․․․․․․

至

들

些焉焉

㣢

灵芯导

品 룽

E

氞垔

ธี

능 ह

ธ $\frac{\pi}{5}$

동

这

洁导

a 2

完范皆 


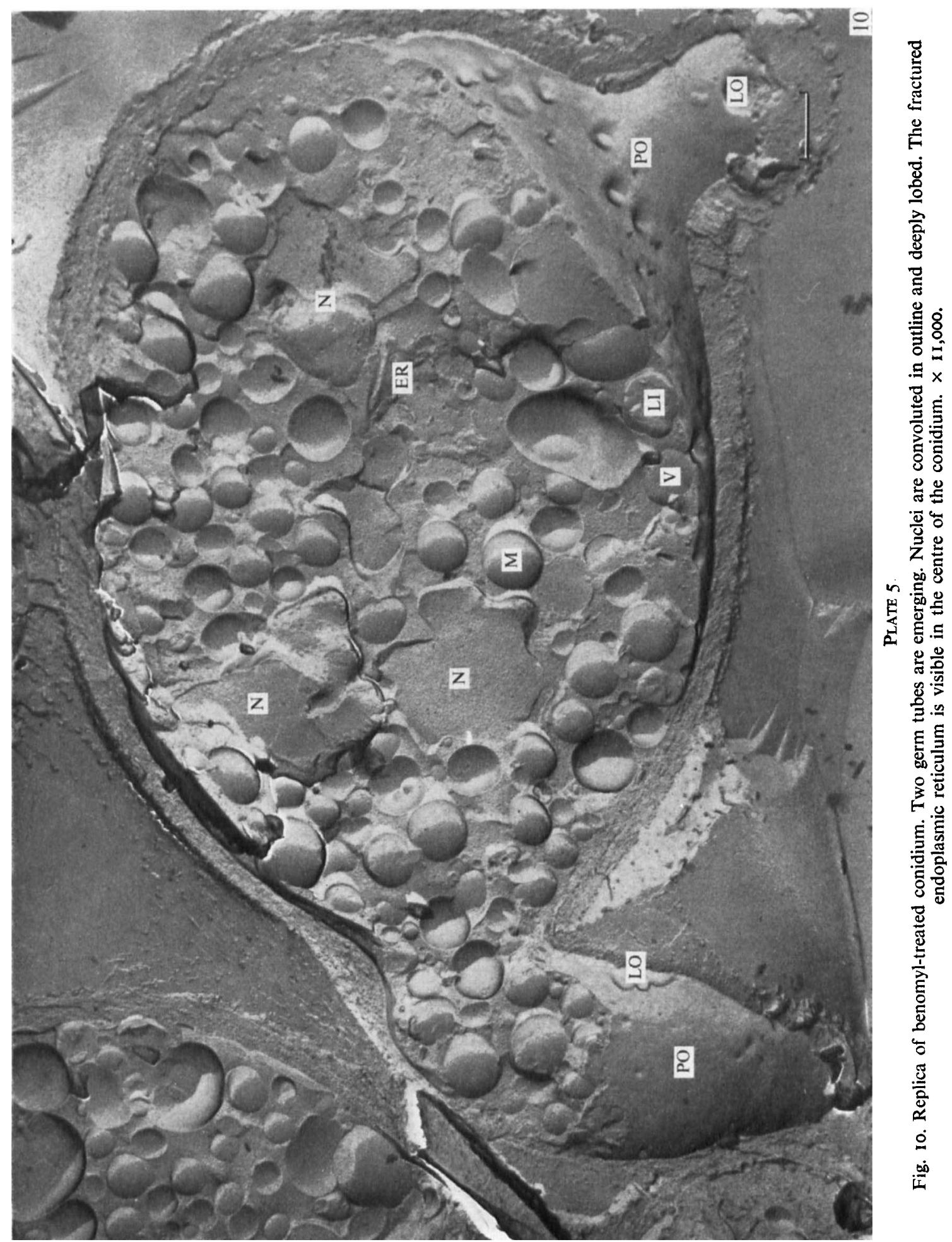



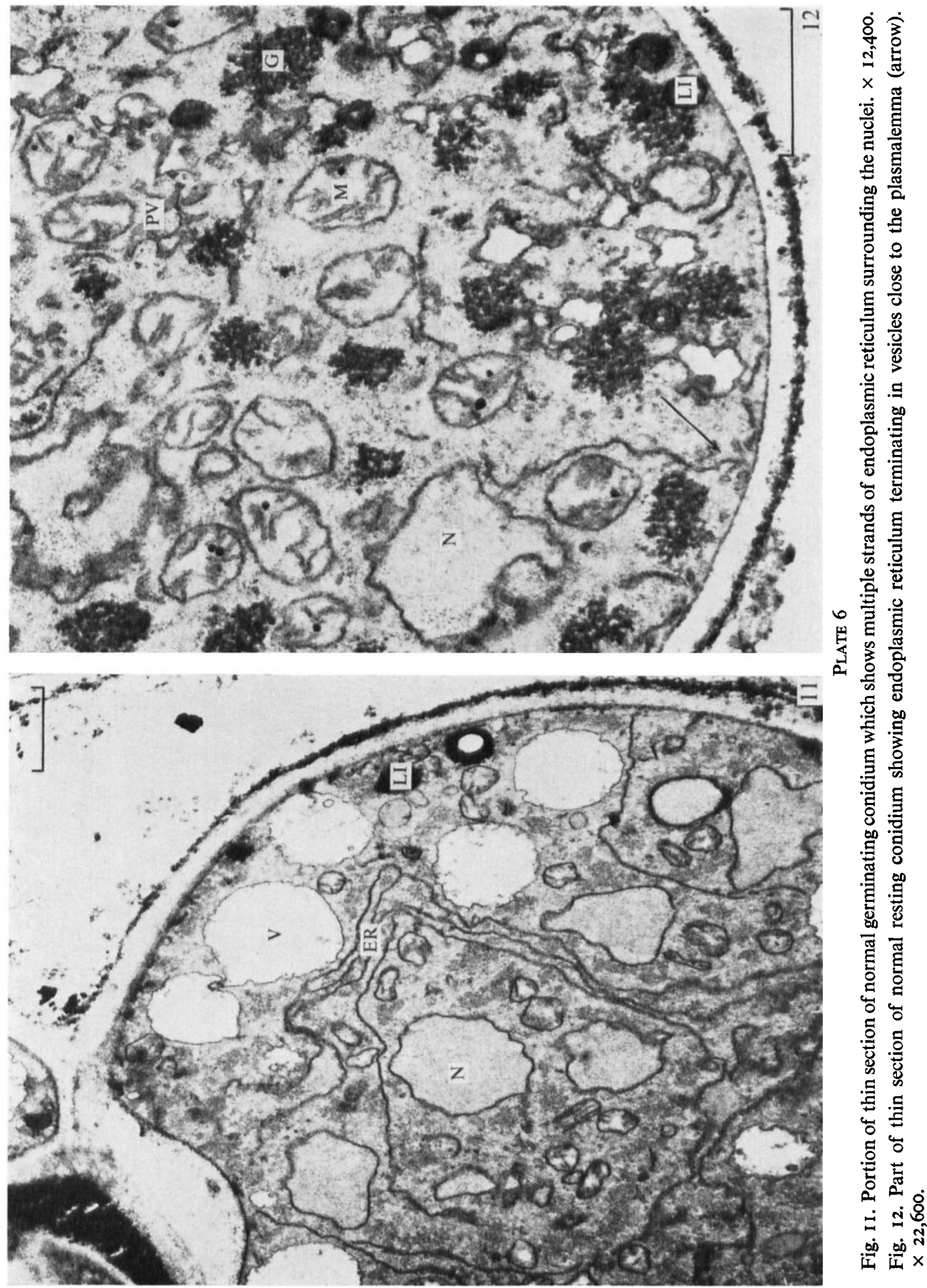

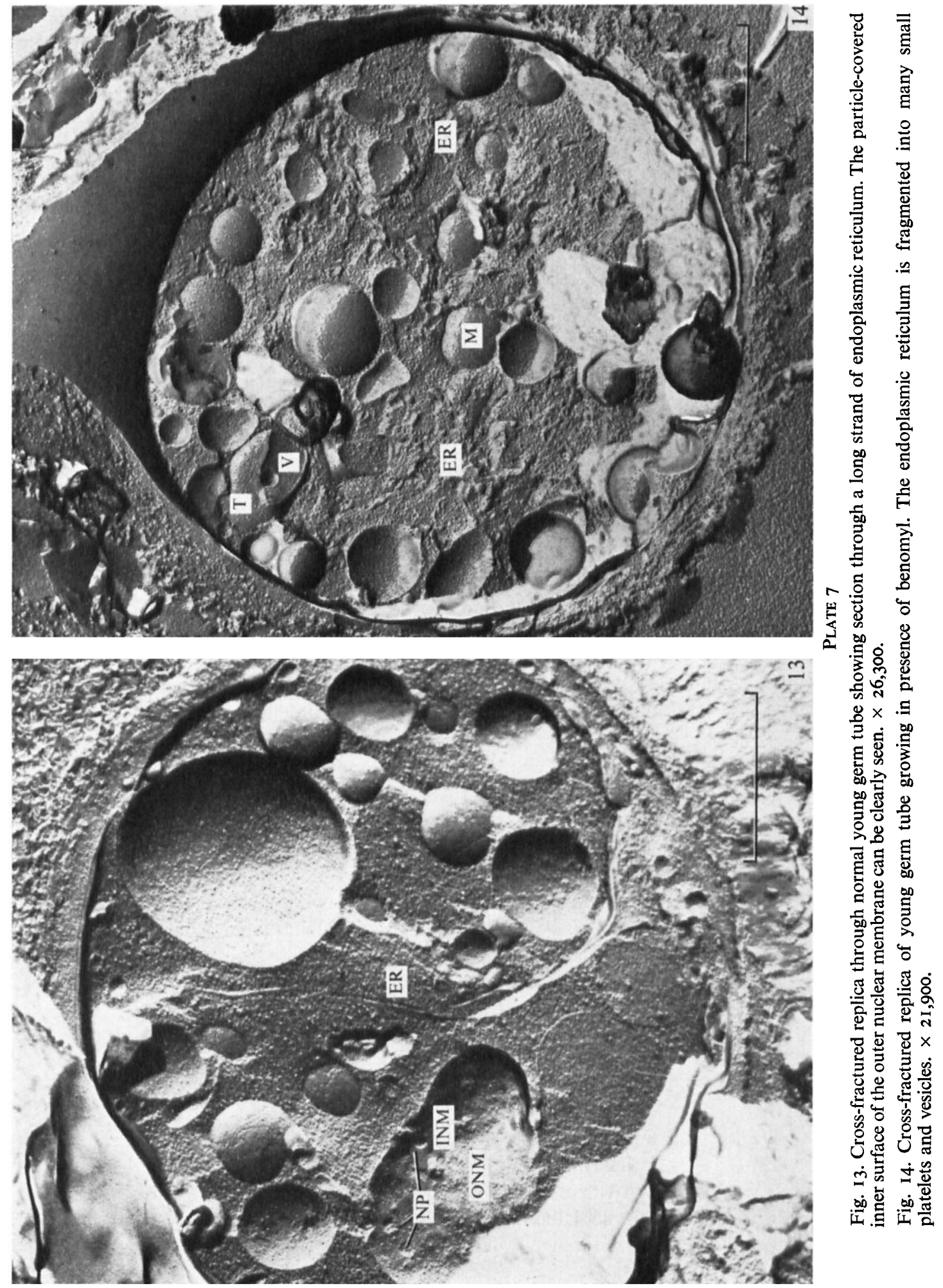
The organelles and endoplasmic reticulum of young germ tubes were usually orientated towards the hyphal tip (PI. 2). This general pattern was disorganized in benomyl-treated cells and the organelles appeared to be directed to several different points on the periphery of the young germ tube (Pl. 3, 4). The form of the endoplasmic reticulum also changed from multiple strands surrounding the nuclei (Pl. 6, fig. II) to short broken fragments and, sometimes, a branched reticulate network (Pl. 3). The few strands of endoplasmic reticulum present seemed to radiate from the nuclei rather than to enfold them (Pl. 3). Some strands of endoplasmic reticulum lay parallel to the plasmalemma and others were directed to positions on the periphery where they terminated in a series of small vesicles (PI. 4 ). This configuration was normally a characteristic of resting conidia (P1. 6, fig. I2).

The results obtained with chemically fixed sections were confirmed by a study of freezefractured replicas. The fragmented endoplasmic reticulum in longitudinal (P1. 5) and transverse (Pl. 8, fig. I6) conidial replicas and transverse germ-tube replicas ( $\mathrm{Pl}$. 7, fig. I4) after benomyl treatment was strikingly different from the multiple sheets in untreated conidia (Pl. 8, fig. I5) and from the long strands in untreated germ tubes (P1. 7, fig. I3). The network of endoplasmic reticulum seen in thin section (Pl. 3) was found in three-dimensional replica to consist of a fragmented series of platelets, tubules and vesicles ( $\mathrm{Pl}$. 7, fig. I4). The appearance of the endoplasmic reticulum surface in Pl. 8, fig. I5 where it passed continuously into a cross-fractured section suggested that the fracture plane passed along the inner or outer membrane surface and that the membrane had not been split.

The inner (Pl. 9, fig. I8) and outer (Pl. I0, fig. I9) surface of the plasmalemma of benomyltreated conidia was far more convoluted than in normal germinating conidia ( $\mathrm{Pl}$. 9, fig. I7). The swellings on the inner surface of the plasmalemma and the depressions on the outer surface were probably due to lomasomes (Richmond \& Pring, I97I $b$ ). The outer surface of the plasmalemma was covered with particles some of which, particularly in the region of the lomasomes, were arranged in an ordered geometrical pattern ( $\mathrm{Pl}$. IO, fig. I9). The appearance of the plasmalemma surface of Botrytis fabae varied considerably in resting conidia, germinating conidia and hyphae (Richmond \& Pring, I97 $a, b$ ) but the ordered arrangement of particles was previously found only in hyphae. Changes in the plasmalemma probably accompanied changes in cell metabolism. Similar variations occurred on the plasmalemma in cells of pea root tips (Northcote \& Lewis, 1968). A cross-fractured replica showed that large numbers of vesicles were present on the cell periphery (Pl. IO, fig. 20). These vesicles probably passed through the plasmalemma by a process of reverse pinocytosis to form lomasomes (Richmond \& Pring, I97I $b$ ).

Benomyl-treated nuclei $(\mathrm{Pl} .3,4)$ were indistinguishable in thin section from those of untreated material (Pl. 2, 6) but freeze-etched replicas showed that treated nuclei were deeply lobed and convoluted ( $\mathrm{Pl}$. 5) whereas normal nuclei appeared smoothly rounded and nearly spherical (Pl. 8, fig. I5).

Mitochondria and lipid bodies appeared unaffected by benomyl (Pl. 5), although some mitochondria had looped cristate membranes (Pl. 4). Benomyl appeared to have little effect on wall thickness (Pl. 2, 3).

\section{DISCUSSION}

The external morphological changes induced in Botyrtis fabae germ tubes by benomyl were reflected in changes in their internal fine structure. The most striking change occurred in the endoplasmic reticulum where the concentric sheets in normal germinating conidia were replaced by a branched reticulated network. Endoplasmic reticulum is highly plastic in form and its appearance can be modified by altering the fixation (Orrenius \& Ericsson, 1966). 

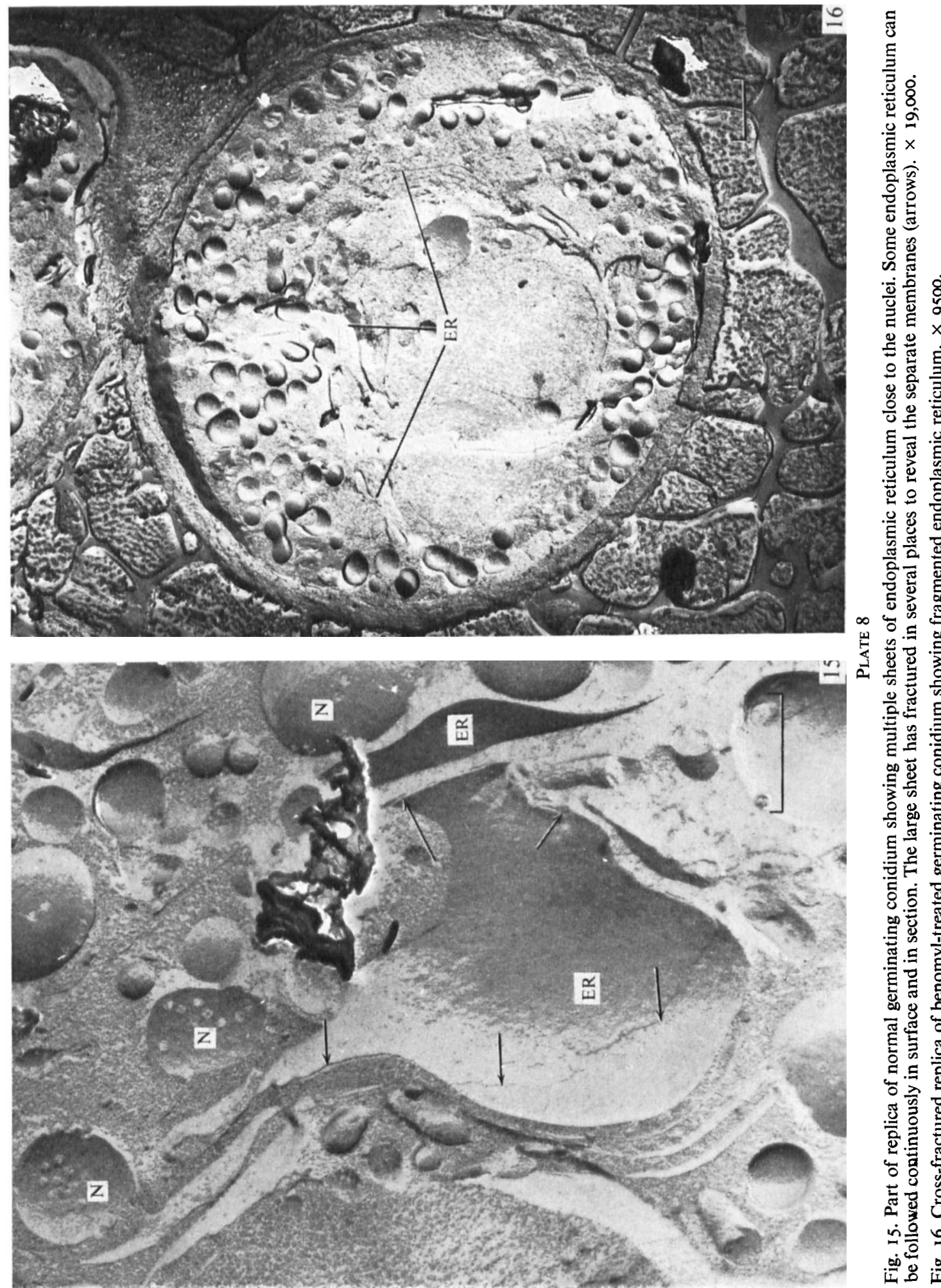
思若要

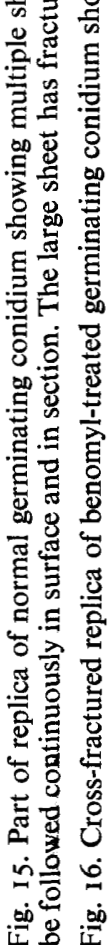



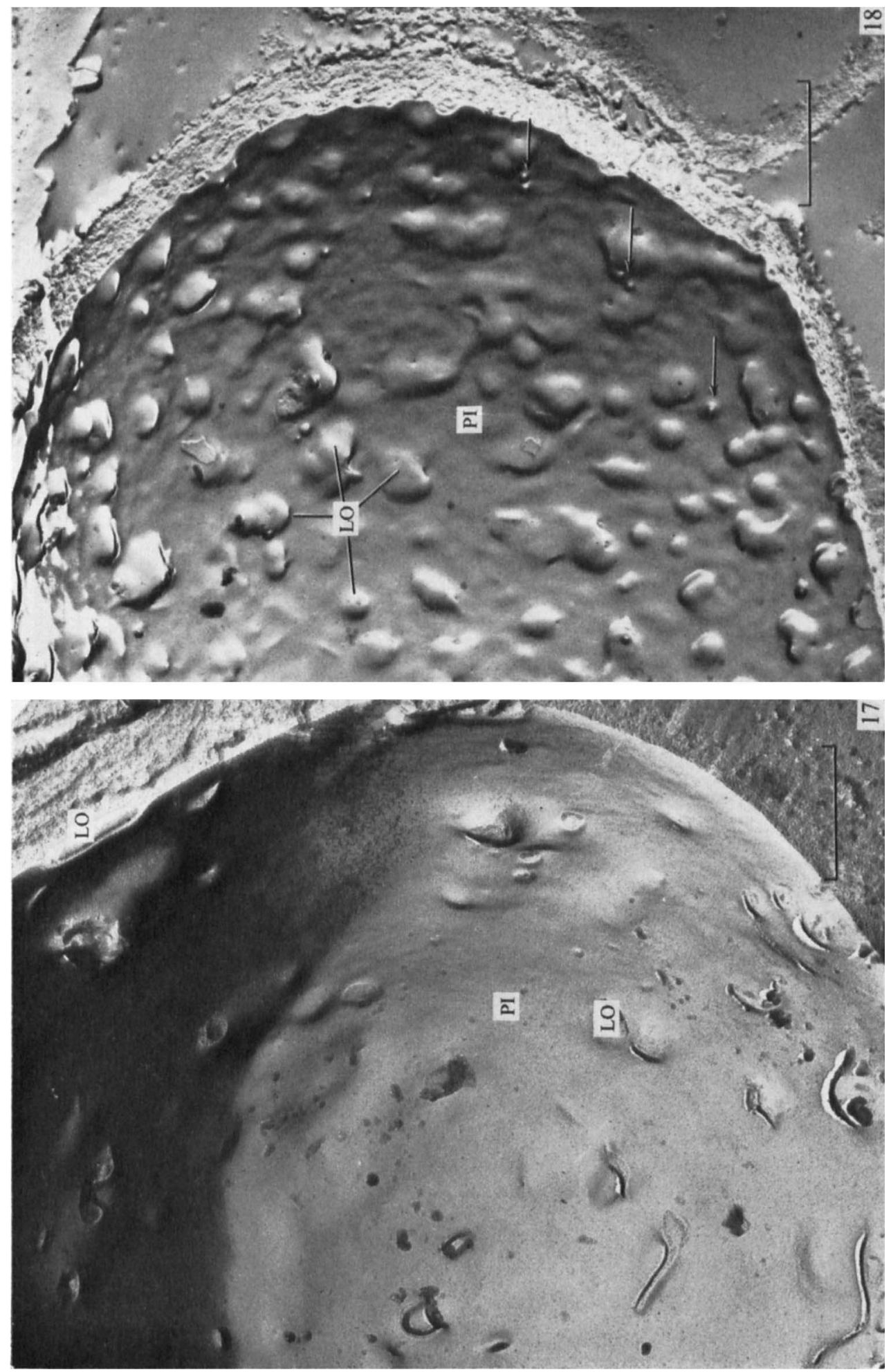

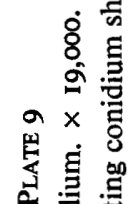

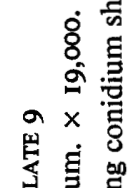

ठั.

on

䛼

.

总

沯

ह

잉

范

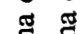

है है

类

घี

蛋

पे क्षे

\% 吾

品

至

氙

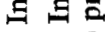

$5 \stackrel{0}{5}$

完 

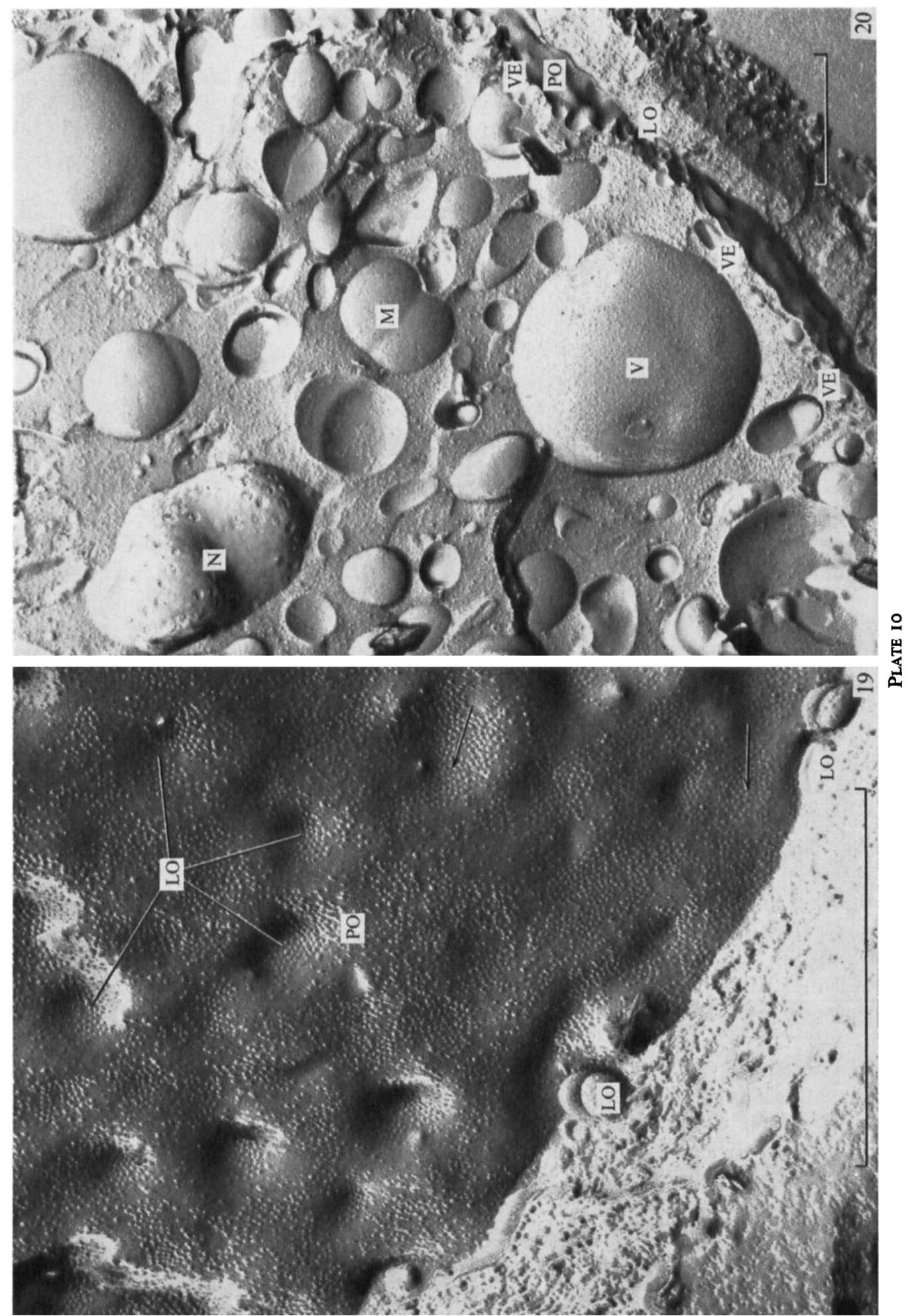

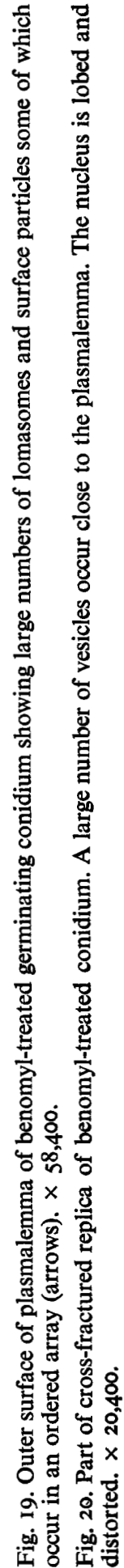


The changes in $B$. fabae, were probably real, however, since treated and untreated material were fixed under the same conditions, and furthermore the fragmented endoplasmic reticulum could be clearly seen in freeze-etched replicas where the possibility of fixation artefacts does not arise. The alterations in the form of the endoplasmic reticulum in benomyl-treated cells suggest that the fungicide may have affected an essential metabolic activity controlling the direction of cellular activities. Strands and vesicles of endoplasmic reticulum at the periphery of resting conidia may plasticize the wall prior to germ-tube emergence (Moor, 1967). The presence of similar structures in benomyl-treated germ tubes may have been connected with the distortions produced by the fungicide. A rapid increase in endoplasmic reticulum occurs when many fungal spores germinate, but germinating sporangiospores of Mucor rouxii (Bartnicki-Garcia, Nelson \& Cota-Robles, 1968) and Rhizopus stolonifer (Buckley, Sommer \& Matsumoto, 1968) produce very little endoplasmic reticulum. The different organization of endoplasmic reticulum in Phycomycetes may be associated with their relative resistance to benomyl (Delp \& Klopping, 1968).

The increase in the number of lomasomes in treated conidia (Pl. 9, fig. I8) was probably directly connected with the changes in endoplasmic reticulum since lomasomes are formed by the passage through the plasmalemma of vesicles derived from the endoplasmic reticulum (Richmond \& Pring, I97I $b$ ). Smith \& Marchant (I969) found that chloramphenicol induced the formation of similar organelles in Rhodotorula glutinis.

Benomyl induces the formation of haploid segregants in diploid strains of Aspergillus nidulans (Hastie, 1970). Electron microscopy revealed little of the internal structure of the nucleus of Botrytis fabae and both treated and untreated nuclei appeared very similar in thin sections and in replicas of cross-fractured surfaces. The deeply lobed and convoluted appearance of freeze-etched nuclei in treated conidia (Pl. 5) may, however, indicate some action of benomyl on the nucleus. A convoluted nuclear outline was observed in chemically fixed captan-treated conidia of Neurospora crassa (Richmond, Somers \& Millington, 1967) and was attributed to the reaction of captan with the sulphydryl groups of nuclear proteins.

Other organelles were little affected by benomyl, although some mitochondria had looped cristate membranes (P1. 4) similar to those in chloramphenicol-treated cells of Rhodotorula glutinis (Smith \& Marchant, I968). Similar mitochondrial profiles occur, however, in untreated conidia of Botrytis cinerea (Buckley, Sjaholm \& Sommer, I966) and as benomyl has little effect on respiration (Sijpesteijn \& van der Kerk, 1969) the compound would not be expected to alter mitochondrial structure.

The morphological and morphogenetic changes induced in fungi by antibiotics have been reviewed by Betina, Betinová \& Kutková (1966). Antibiotics such as cyanein, actinomycin $\mathrm{C}$, griseofulvin and actidione which interfere with the biosynthesis of nucleic acids and protein all induce morphological changes in Botrytis cinerea. The fungicides tecnazine and dicloran also produce swollen and branched germ tubes in $B$. cinerea growing on agar (Esuruoso, Price \& Wood, 1968) resembling the effects of benomyl. Dicloran is an inhibitor of protein synthesis (Weber \& Ogawa, 1965).

The possible mode of action of benomyl has been discussed by Sisler (1969) and by Sijpesteijn \& van der Kerk (1969). Benzimidazole itself delays senescence in detached wheat leaves (Person, Samborski \& Forsyth, 1957) and benzimidazole nucleoside is a product of benzimidazole metabolism. A nucleotide derivative may therefore be the actual fungi toxicant. The inhibition of cell division by the carbamate group may be a secondary effect; carbamates are known to disorient microtubules involved in spindle formation (Banerjee \& Margulis, 1969). 
Benomyl inhibits sporulation of Mycosphaerella musicola on banana leaves (Stover, 1969) and Botrytis fabae on broad bean leaves (D. V. Richmond \& R. J. Pring, unpublished). At higher concentrations mycelial growth is inhibited; even higher concentrations are required to prevent spore germination (Clemons \& Sisler, 1969). Although high concentrations will kill $B$. fabae spores, the action of benomyl is essentially fungistatic at the concentrations we have used. Spores which have been completely inhibited from germinating will germinate normally when transferred to a benomyl-free medium. In a similar manner the distorted germ tubes produced by benomyl form a single hypha and grow normally in the absence of the fungicide. Most fungicides act by non-specific enzyme inhibition (Somers, 1968): benomyl may have a different, more specific, mode of action (Sisler, 1969).

The authors wish to thank the Biochemistry Department, University of Bristol for the use of their electron microscope and freeze-etching apparatus, Mr A. Brittain of that Department for helpful assistance with freeze-etching, and Miss Elizabeth Hull for the Stereoscan photographs.

\section{REFERENCES}

BanerJee, S. \& Margulis, L. (I969). Reversible inhibition of cilia regeneration in Stentor coeruleus by isopropyl- $n$-phenyl carbamate. Nature, London 224, I80-I 8I.

Bartnicki-Garcia, S., Nelson, N. \& Cota-Robles, E. (I968). Electron microscopy of spore germination and cell wall formation in Mucor rouxii. Archiv für Mikrobiologie 63, 242-255.

Betina, V., Betinová, M. \& KutKová, M. (I966). Effects of cyanein on growth and morphology of pathogenic fungi. Archiv für Mikrobiologie 55, I-I6.

Buckley, P. M., SJaholm, V. E. \& Sommer, N. F. (1966). Electron microscopy of Botrytis cinerea conidia. Journal of Bacteriology 9r, 2037-2044.

Buckley, P. M., Sommer, N. F. \& Matsumoto, T. T. (1968). Ultrastructural details in germinating sporangiospores of Rhizopus stolonifer and Rhizopus arrhizus. Journal of Bacteriology 95, 2365-2373.

Clemons, G. P. \& Sisler, H. D. (1969). Formation of a fungitoxic derivative from benlate. Phytopathology 59, 705-706.

Delp, C. J. \& Klopping, H. L. (1968). Performance attributes of a new fungicide and mite ovicide candidate. Plant Disease Reporter 52, 95-99.

Esuruoso, O. F., Price, T. V. \& Wood, R. K. S. (I968). Germination of Botrytis cinerea conidia in the presence of quintozene, tecnazine and dicloran. Transactions of the British Mycological Society 51, 405-4IO.

GreEnhalgh, G. N. \& Evans, L. V. (1968). The developing ascospore wall of Hypoxylon fragiforme. Journal of the Royal Microscopical Society 88, 545-556.

HASTIE, A. C. (1970). Benlate-induced instability of Aspergillus diploids. Nature, London 226, $77 \mathrm{I}$.

Hislop, E. C. (1967). Observations on the vapour phase activity of some foliage fungicides. Annals of Applied Biology 6o, 265-279.

Miller, P. M. (1969). Suppression by benomyl and thiabendazole of root invasion by Heterodera tabacum. Plant Disease Reporter 53, 963-966.

Moor, H. (1966). Use of freeze etching in the study of biological ultrastructure. International Review of Experimental Pathology 5, 179-2 I6.

Moor, H. (1967). Endoplasmic reticulum as the initiator of bud formation in yeast (S. cerevisiae). Archiv für Mikrobiologie 57, 136-146.

NorthсотE, D. H. \& LEWIS, D. R. (1968). Freeze-etched surfaces of membranes and organelles in the cells of pea root tips. Journal of Cell Science 3, 199-206.

OrRenius, S. \& Ericsson, J. L. E. (1966). On the relationship of liver glucose-6-phosphatase to the proliferation of endoplasmic reticulum in phenobarbital induction. Journal of Cell Biology 3r, 243-256.

Person, C., Samborski, D. J. \& Forsyth, F. R. (I957). Effect of benzimidazole on detached wheat leaves. Nature, London 180, $1294-\mathrm{I} 295$.

Richmond, D. V. \& Pring, R. J. (I97Ia). Fine structure of Botrytis fabae Sardiña conidia. Annals of Botany $35,175-182$.

Richmond, D. V. \& Pring, R. J. (1971 b). Fine structure of germinating Botrytis fabae Sardiña conidia. Annals of Botany 35, 493-500. 
Richmond, D. V., Somers, E. \& Millington, P. F. (1967). Studies on the fungitoxicity of captan. V. Electron microscopy of captan-treated Neurospora crassa conidia. Annals of Applied Biology 59, 233-237. SuJPESTEIJN, A. K. \& VAN DER KeRK, G. J. M. (I969). Biochemical modes of action of fungicides. Proceedings of the Fifth British Insecticide and Fungicide Conference, vol. 3, pp. 724-733.

Sims, J. J., MeE, H. \& ERwiN, D. C. (1969). Methyl 2-benzimidazolecarbamate, a fungitoxic compound isolated from cotton plants treated with methyl I-(butylcarbamoyl)-2-benzimidazolecarbamate (benomyl). Phytopathology 59, 1775-1776.

SisLer, H. D. (1969). Effect of fungicides on protein and nucleic acid synthesis. Annual Review of Phytopathology 7, 3I I-330.

Smith, D. G. \& Marchant, R. (1968). Chloramphenicol inhibition of Pythium ultimum and Rhodotorula glutinis. Archiv für Mikrobiologie 60, 262-274.

SMITH, D. G. \& MARCHANT, R. (1969). Unbalanced cell-wall synthesis in chloramphenicol-grown Rhodotorula glutinis. Antonie van Leeuwenhoek 35, I1 3-I 19.

Somers, E. (1968). Transport and accumulation of fungicides by fungal conidia. S.C.I. Monograph 29, 243-250.

STOVER, R. H. (1969). The effect of benomyl on Mycosphaerella musicola. Plant Disease Reporter 53, 830-833.

WEBER, D. J. \& OGAWA, J. M. (1965). The mode of action of 2,6-dichloro-4-nitroaniline in Rhizopus arrhizus. Phytopathology 55, 159-165. 